\title{
Constructive-feedback: an educational district forma theory to practice in ELF teacher education
}

\author{
Delaram Pourmandnia ${ }^{1, a}$, Behnam Behfrouz ${ }^{2, b}$ \\ ${ }^{1}$ Islamic Azad University, South Tehran Branch, Iran \\ ${ }^{2}$ Payam Noor University, Joveyn, Iran \\ ${ }^{a, b}$ E-mail address: D_pnia@yahoo.com , Behnambehfrouz@hotmail.com
}

\begin{abstract}
The aim of this study is to familiarize the readers with some key and basic issues about feedback which is an educational district these days, in a coherent and tangible manner. In this paper, through using relevant literature, issues such as teacher education, good language teaching constructive feedback, types of feedback and its effect on educational environment of language teachers are discussed.
\end{abstract}

Keywords: Constructive feedback; Teacher education

\section{INTRODUCTION}

\section{Teacher Education}

The issue of teacher education enjoys a multidimensional scope for consideration; however, its programs, selves, standards and behaviors seem to energize a remarkable degree of professional identity development. Likewise, it can be said from another point of view that the constant provision of feedback on the side of teacher can have profound constructive impact on the behavioral traits of them. Relatively speaking, Garry F. Hoban (2004) concludes that the quality of existing teacher education programs is currently being debated in many countries and at many educational levels. He examines the nature of teaching and challenges the common mechanistic approach to teacher education design. If teaching is a complex profession, then a more integrated and dynamic approach to designing teacher education programs is needed. In this regard, he proposes a four-dimensional approach for thinking about a conceptual framework to guide teacher education design. The four dimensions include: (a) links across the university-based curriculum; (b) links between schools and university experiences; (c) sociocultural links between participants; and (d) personal links that shape the identity of teacher educators. It is argued that a conceptual framework based upon the consideration of these four dimensions is likely to ensure quality in a teacher education program. Moreover, According to Marilyn Cochran-Smith (2005) new teacher education has been emerging with three closely coupled pieces. It is constructed as a public policy problem, based on research and evidence, and driven by outcomes. Illustrating and critiquing each of these pieces, it is said that the new teacher education is both for the better and for the worse. He concludes that education scholars who care about public education must challenge the narrowest aspects of the emerging new 
teacher education, building on its most promising aspects and working with others to change the terms of the debate.

\section{Teaching and Teacher Education}

Scholars view the emergence of language teaching trend differently. It seems that language teaching came into its own as a profession in the last century. Central to this phenomenon was the emergence of the concept of "methods" of language teaching. The method concept in language teaching - the notion of a systematic set of teaching practices based on a particular theory of language and language learning - is a powerful one, and the quest for better methods was a preoccupation of teachers and applied linguists throughout the 20th century. (Richards \& Rodgers, 2001).In this trend, language teaching is the essential research resource for language professionals as it provides a rich and expert overview of research in the field of second-language teaching and learning.

\section{Language Teaching Methodology- Practices Defined}

Methodology in language teaching has been treated in different ways. A more or less classical formulation suggests that methodology is that which links theory and practice. Theory statements would include theories of what language is and how language is learned or, more specifically, theories of Second Language Acquisition (SLA). Such theories are linked to various design features of language instruction.

Design features in turn are linked to actual teaching and learning practices as observed in the environments where language teaching and learning take place. This whole complex of elements defines language teaching. (Widdowson, 2003, Richards \& Rodgers, 2001).

\section{Good Language teaching}

It can be said that for both pedagogical and educational reasons it is important to know what it is that makes language teaching good language teaching. Surveys have been conducted to find out what the good language learner does. But language teaching and language acquisition are complicated entities and it is difficult to point to what exactly it is in teaching that results in learning.

All language teachers have experienced activities being a success in one class but an absolute failure in the next. Good language teaching in practice is, then, to a great extent a series of relative processes, it is only good if it is constantly adapted to particular students' needs, potential and situation. Bearing on the discussion posed above, Lund and Pedersen (2001) suggests four ways for good language teaching and of its importance. First, good language teaching opens up the possibility for a communicative learning forum. Second, good language teaching creates linguistic attention in relation to the content-oriented communication.

Third, good language teaching helps the students assume responsibility for their own learning. Fourth, Good language teaching breaks down walls. Language teaching styles and strategies nowadays have been of outmost importance among scholars as they characterize what a good language teaching is.

\section{Constructive feedback}

Constructive feedback refers to the professional comments and recommendations aimed at betterment and development of professional identity of EFL teachers and which are given by a language professional mentor and advisor to EFL teacher in response to his classroom and academic behavior in carrying out his teaching career. 
Bee and Bee (1996, p.3) defend that feedback is constructive when "there are agreed standards of behavior and performance, and two-way communication about what has gone right as well as what has gone wrong" and when it "supplies information about behavior and performance against objective standards in such a way that recipients keep a positive attitude towards themselves and their work". Meanwhile, according to Irons $(2008$, p.55) constructive feedback "should be proper to the formative evaluation and to the student learning process". On the other hand, Sangster and Overall (2006, p.123) are of the opinion that "giving constructive formative feedback carries the implication that there will be information available which helps you to improve your work".

\section{The Emotional Impact of Providing Feedback}

"Feedback is one of the most powerful influences on learning and achievement, but this impact can be either positive or negative" (Hattie \& Timperley 2007, p. 81). The emotional impact that assessment has on learners plays a important role in their achievement (ARG 2002:2; Stiggins 2008b).

It can be seen that providing constructive feedback that focuses on the learner's progress toward the desired standard, rather than on the learner self, is more productive. According to (ARG 2002, 2006; Black \& Wiliam 1998; Hattie \& Timperley 2007; Stiggins 2008) if learners are merely provided with a mark or grade, the assessment is mainly judgmental and learners are focused on comparing themselves to others rather than using the feedback to improve. Feedback is counterproductive when it results in learners feeling that they are not good enough, and impacts negatively on their confidence and enthusiasm to learn. Feedback is more constructive when it focuses on what the learner does well rather than highlighting failure. Learners' mistakes and misconceptions can be addressed if the feedback is focused on their work, providing guidance on how they can improve.

Hattie and Timperley $(2007$, p.98) point out that praise can be effective, provided it is accompanied by feedback about the task. Essentially, only providing learners with grades showing their failure, instead of feedback that diagnoses incorrect mental models and corrects misunderstanding, is detrimental to their learning. Hattie and Timperley (2007, p.104) state that "the major discriminator is whether [the feedback] is clearly directed to the task, processes and not to the self level". Stiggins (2008b, p.8) accepts: "If all students are to succeed, they must have continuous access to sufficient evidence of their own academic success at mastering prescribed achievement standards".

Constructive feedback has been of great interest to both Second Language (SL) and Foreign Language (FL) researchers likewise. In the same way, a growing body of research has investigated the potential efficacy of Written Constructive Feedback (WCF) and its roles in language learners' writing development in different ways.

The effectiveness of WCF has been controversial regarding whether error correction is beneficial to the learning process or not. On the one hand, CF has proved to be effective in promoting language learning (Sheen, 2007; Lee, 1997), yet on the other hand, as Truscott (1996) claimed, it could be obstructive or even detrimental. In an extreme view on CF, Truscott (1996) argued that the application of CF on the learners' writing should be totally avoided as it hinders and harms writing development. According to Truscott (1996), "grammar correction has no place in writing courses and should be abandoned" (p. 328).

On the contrary, more recent studies support the positive contributions of CF to language learning and in particular writing skills (e.g., Bitchener \& Knoch, 2008; Sheen, 2007). CF also enables learners to notice the "gap" between their interlanguage and the target language resulting in more focused and accurate learning. Additionally, in accordance with general 
research on language learning, $\mathrm{CF}$ studies have specifically focused on the ways $\mathrm{CF}$ can alter and promote "learning processes" and "linguistic competence" (Sheen, 2010b, p. 204).This, in turn, enables language learners to concentrate their attention on syntactical structures of their language products resulting in better learning of linguistic forms. Lee (2003) argue that the main concern nowadays is not to whether provide CF for the learners but rather "when and how to provide feedback on the students' errors" (p. 349). Similarly, Schmidt's (1990, 1995, 2001) Noticing Hypothesis suggests that noticing the gap between interlanguage and the target form is a prerequisite of learning, as long as conscious awareness of the input is present. Thus, $\mathrm{CF}$ provides learners with clues indicating what is wrong and draws their attention to erroneous forms resulting in better learning.

Russell and Spada (2006) further stated that CF is helpful for L2 learning. Erel and Bulut (2007) refer to various studies (e.g., Ferris \& Roberts, 2001) for "motivating" and "encouraging" effects of WCF on learners and state that, "it is believed ... that if a teacher indicates a written grammatical error on a student's paper and provides the correct form in one or another way, the student will realize the error and will not repeat it in his/her future writings" (p. 398).

Additionally, Ferris and Roberts's (2001) experiment with different types of WCF substantiated the efficacy of CF on improving learners' writing accuracy. Numerous studies show the effectiveness of $\mathrm{CF}$ in promoting Writing as well as grammatical accuracy of the learners. Ashwell (2000) also states that teachers believe that correcting the grammar of student writers' work will help them improve the accuracy of subsequent writing.

Research evidence on error correction in L2 writing classes shows that students who receive error feedback from teachers improve in accuracy over time (Ferris \& Roberts, 2001). There is also research evidence which proves that students want error feedback and think that it helps them improve their writing skill in the target language (Leki, 1991; Ferris \& Roberts, 2001; Chandler, 2003).

Similarly, Leki (1991) and Zhang (1995) in their studies found out that the learners themselves greatly appreciate teacher-provided CF regarding their writings. This clearly shows that "L2 students have positive attitudes towards written feedback" (Kaweera\& Usaha, 2008, p. 86).

It is also worth mentioning that, "many scholars and researchers agree that feedback is essential and has a positive effect on students' writing. Thus, feedback on writing can be selected as a means of helping students to make revision and can help students improve their writing skills" (Kaweera \& Usaha, 2008, p. 85).

Given the aforementioned findings and studies, it becomes apparent that despite earlier controversy over the effectiveness of CF provided by teachers on learners' writing, it is obvious that $\mathrm{CF}$ plays a crucial role in promoting learning processes and eliminates learners' structural problems regarding what they produce especially in written form. Teachers should also be aware of learners' needs which are the basis for appropriate feedback teachers intend to provide as there are different types of feedback ranging from explicit to implicit. This is because learners vary in their knowledge and level of proficiency and therefore, "can benefit from different ways of providing corrective focus on form" (Guenette, 2007, p. 47).

\section{Various Strategies to Provide Feedback}

If learners are given only marks or grades, they do not benefit from the feedback on their work. If learners are only rewarded by a quantitative score, they perceive the purpose of assessment as being summative, to rank the class in order of ability so that they can be compared to their peers (Black \& Wiliam, 2008; Stiggins, 2008b). 
So, the form of reporting and providing feedback must be consistent with the purpose of the analyzing (Swan, 1993, p.26). The feedback on test results is provided to learners so that they can identify their own strengths and weaknesses are a critical feature. Black and Wiliam (2008, p. 8) note that "a good test can be a learning as well as a testing occasion". By analyzing test results, teachers can know and understand learning difficulties and misconceptions and can provide feedback accordingly. If a test is given at the end of a module, it cannot serve formative goals. Black and Wiliam (2008, p. 8) note, however, that too often "the collection of marks to fill up records is given greater priority than the analysis of students' work to comprehending learning needs".

Class work and homework exercises can also be used as an invaluable opportunity to provide constructive feedback to learners provided the tasks are clear and relevant to the learning goals (Black \& Wiliam 2008). Maree and Fraser (2008) suggest that teachers could make rules for learners to hand in draft copies of their work, and then write comments on or discuss these with the learners. In this way learners develop their work with the teacher, as opposed to just handing in a completed product.

A study conducted by Darr and Fisher (2004) in a grade 7 class to explore how a learning and teaching environment could support self-regulated learning, involved encouraging mathematics learners to report and explain their thinking by keeping a journal. The written feedback by the authors, who read the journals after each session, encouraged further reflection by the learners. Feedback from the journaling in turn was used to do first discussion about learning on a whole class or group bases. They assert that the journals provided learners the opportunity to reflect on their thinking and enabled the teacher to achieve insights into the strategies used by learners.

Feedback can also be provided by means of report cards. Maree and Fraser (2008, p. 157) suggest that report cards can assist in improving learning if learners are provided with "accurate feedback about the state of their learning". Whichever feedback strategies are employed, it is important to note that the learner's emotional response to any form of feedback plays a sufficient and important role in whether the learner can and will use this feedback to improve or self-correct.

\section{Types of Constructive Feedback}

According to Lyster and Ranta (1997), different types of CF have been identified including explicit, metalinguistic, elicitation, repetition, recast, translation, and clarification requests.

\section{Explicit}

Explicit feedback falls at the explicit end of corrective feedback spectrum. Rezaei et al. (2011) cite Ellis, Loewen, and Erlam (2006) and mention that this type of feedback "is characterized by an overt and clear indication of the existence of an error and the provision of the target-like reformulation and can take two forms, i.e. explicit correction and metalinguistic feedback" (p. 23). In explicit CF, teacher clearly draws learner's attention to the erroneous part(s) and provides correct structures directly.

\section{Metalinguistic Feedback}

As characterized by Rezaei et al. (2011), "much like explicit error correction, metalinguistic feedback- because it diverts the focus of conversation towards rules or features of the target language- falls at the explicit end of the corrective feedback spectrum." (p. 23). 


\section{Elicitation}

In this type of CF, self-correction is emphasized (Panova \& Lyster, 2002). Regarding this type of CF, Rezaei et al. (2011) propose three different ways during FtF interaction varying in their level of explicitness or implicitness. The first strategy "is request for reformulations of an ill-formed utterance. The second one is through the use of open questions. The last strategy which is ... the most implicit is the use of strategic pauses to allow a learner to complete an utterance." (p. 24).

\section{Repetition}

This type of CF, according to Rezaei et al. (2011), "is less communicatively intrusive in comparison to explicit error correction or metalinguistic feedback and hence falls at the implicit extreme on the continuum of corrective feedback." (p. 24).

\section{Recast}

According to Rezaei et al. (2011), numerous studies (e.g., Nelson, Carskaddon, \& Bonvillian, 1973; Nicholas et al., 2001) indicate that "The term recast was initially used in the literature of L1 acquisition to refer to responses by adults to children's utterances ...; afterward it merged into the domain of L2 acquisition in which different definitions were utilized for this term.” (p. 22).According to Ellis and Sheen (2006, pp. 78-80), recasts are of various types including corrective recasts (Doughty \& Varela, 1998), corrective/non-corrective recasts (Farrar, 1992), full/partial recasts, single/multiple recasts, single utterance/extended utterance recasts, and simple/complex recasts (Ellis \& Sheen, 2006).

\section{Translation}

Translation was regarded as a subdivision of recast (Lyster\&Ranta, 1997). But, according to Rezaei et al. (2011), the difference between translation and recast is that "the former is generated in response to a learner's ill-formed utterance in the target language while the latter is generated in response to a learner's well-formed utterance in a language other than the target language." (p. 24).

\section{Clarification Requests}

According to Rezaei et al. (2011), this kind of feedback "carries questions indicating that the utterance has been ill-formed or misunderstood and that a reformulation or a repetition is required" (p. 23).

This type of feedback unlike explicit error correction, recasts, and translations, can be more consistently resorted to in order to generate modified output due to the fact that it might not provide the learners with any information regarding the type or location of the errors made. Thus, they demand deeper levels of mental processing required by the learners to produce target-like forms and therefore are more beneficial to high-level learners.

\section{Findings on Different Types of Written CF (WCF)}

In order to explore the issue of $\mathrm{CF}$ in writing development, numerous researchers and scholars have focused on the effectiveness of different types of CF in dealing with learners' errors in writing and various outcomes have been reported. These studies have focused on the continuum ranging from explicit (direct) to implicit (indirect) $\mathrm{CF}$. 
Generally, Sheen et.al (2009) support CF and its contribution to writing development and learning by mentioning that " $\mathrm{CF}$ may enhance learning by helping learners to (1) notice their errors in their written work, (2) engage in hypotheses testing in a systematic way and (3) monitor the accuracy of their writing by tapping into their existing explicit grammatical knowledge" (p.567).

According to Ellis (2009) and Bitchener (2008) findings, explicit CF provides learners with direct information as to what has gone wrong especially if learners are not proficient enough to come up with a solution to the problem.

Explicit CF has also proved to enhance acquisition of certain grammatical structures (Sheen, 2007). As opposed to explicit CF, indirect CF provides learners with no overt indicator as to what has gone wrong nor does it provide the corrected structures. Instead, some clues or hints attract their attention to the problematic areas (Ferris \& Roberts, 2001). It has also been argued that explicit CF, by nature, does not involve learners in deep internal processing as it is the case in implicit CF.

Therefore, indirect $\mathrm{CF}$ is more probable to result in long-term learning than direct $\mathrm{CF}$ (Ferris \& Roberts, 2001). In the same vein, Ferris (2002) contends that direct CF is more preferable to indirect CF when dealing with lower-level learners as they have not yet acquired enough grammatical knowledge to self-correct their errors. Recent studies on CF have also supported the positive contribution of feedback to writing improvement (e.g., Chandler, 2003; Bitchener\&Knoch, 2009; Bitchener, 2008).

In an earlier study, Lalande (1982) showed that indirect CF had better results than direct CF in learning promotion. As opposed to Lalande's (1982) findings, Chandler (2003) investigated different types of WCF, including direct and indirect types. He concluded that, direct CF had significant effects on the improvement of learners' writing grammar accuracy.

Liang (2008) also conducted an experiment with different groups of participants receiving different types of WCF as well. Results of this study showed that, both direct and indirect CF helped learners promote certain aspects of their writing such as morphological and syntactic features.

Lightbown and Spada (1990) examined and analysed the effectiveness of explicit CF in an intensive communicative classroom. Their results showed that the teaching of formal aspects helps learners improve their linguistic accuracy. Spada and Lightbown (1993) later conducted another study similar to their previous study demonstrating that explicit CF increased structural accuracy of the learners. Accordingly, another study was conducted by White, Spada, Lightbown, and Ranta (1991) comparing the effectiveness of explicit and implicit CF over no feedback and reported positive results. Likewise, according to Campillo (2003), alongside with explicit CF "implicit corrective feedback has also been widely investigated and can be implemented in different ways" (p. 211).

Kim and Mathes (2001) examined the effectiveness of explicit CF, i.e., metalinguistic, and implicit $\mathrm{CF}$, i.e., recasts. Their findings revealed that both explicit and implicit CF were quite effective in diminishing the chances of error repetition in the future. They also concluded that it would be more beneficial to learners if teachers provide them with "incessant" flow of CF over a more prolonged period of time. In a survey conducted by Ancker (2000), it was concluded that most of the surveyed learners corroborated the application of CF by teachers as often as possible, whereas teachers indicated that it is not necessary to correct errors all the time as it might hinder negotiation of meaning among learners. Nabel and Swain (2002) also investigated the degree of learners' awareness towards CF provided by the teacher. They found that during the experiment, participants could successfully identify recasts given be the 
teachers. Moreover, they discovered that recasts are more effective regarding student centered interaction rather than teacher-centered communication.

Carpenter et.al (2006) argue that recasts are ambiguous and even perplex learners. They also conclude that teachers need to provide more evidence and information for learners to recognize recasts.

Numerous studies (e.g., Lyster\&Ranta, 1997; Panova\&Lyster, 2002) revealed that recasts are the most frequently used type of CF. Lyster and Ranta (1997) also conclude that recasts are beneficial as they reduce the possibility of interruption in the flow of communication of meaning.

Campillo (1993) also argues that, "nevertheless, not all corrective feedback techniques have been regarded as equally effective" (p. 212). He also refers to some recent studies (e.g., Lyster, 1998) and states the need "to explore the effect of combinations of corrective feedback, as opposed to isolated techniques" (p. 212).

In conclusion, researchers have sought to provide evidence and plausible answers to the questions proposed by Hendrickson (1978) but they have not yet been successful in drawing a clear picture of different aspects of CF. These five questions on CF have been the basis for most of the ongoing studies in this field. questions:

According to Hendrickson (1978), CF generally should aim at answering the following

"1. Should learner errors be corrected?

2. If so, when should learner errors be corrected?

3. Which learner errors should be corrected?

4. How should learner errors be corrected?

5. Who should correct learner errors?" (p. 389)

The field of corrective feedback, as can be seen from the studies mentioned above, is wide and has many aspects for further investigation. The studies reviewed here have brought new viewpoints and ideas into research areas.

\section{Findings on Oral CF}

In recent years, research has also offered growing body of evidence confirming the effectiveness of oral CF (OCF) on learners overall language learning development. In this sense, Mackey (2006) conducted an experiment focusing on the probable effectiveness of OCF on learners' ability in noticing linguistic structures in SL context. These findings indicated that those who received CF orally performed better in noticing some linguistic features than the control group who received no feedback. As opposed to Mackey's (2006) findings, Eş's (2003) investigation of OCF revealed no significant difference of linguistic accuracy between those who received CF and those who did not. Eş's (2003) findings have been inconsistent with most of the CF studies confirming the efficacy of CF up to now.

Lyster (1998) also found positive evidence regarding the use of implicit CF such as elicitation, clarification requests, and repetition in dealing with syntactic problems. In one study, Ammar and Spada (2006) conducted an experiment evaluating the efficacy of different types of OCF in speaking classes. To conclude, this study also indicated that the application of different OCF techniques help learners promote their interlanguage with respect to their level of proficiency.

In order to investigate the possible effects of OCF on the improvement of learners' interlanguage, Ellis, Loewen, and Erlam (2006) embarked on a study with a similar design to Ammar and Spada's (2006) experiment. In this study, two experimental groups received recasts 
and metalinguistic types of CF. Findings of this study revealed that the experimental groups performed significantly better than the control group who received no CF in their understanding of linguistic structures. Regarding experimental groups, metalinguistic CF proved to be more effective than recasts.

\section{Computer-Mediated CF}

Computer technologies have been considered to be quite effective in enhancing learning and teaching conditions. According to Loewen and Erlam (2006), "while most of the research that has focused on interaction has taken place in the language classroom, there is increasing recognition of the importance of the computer in providing opportunities for learner interaction" (p. 1). Accordingly, "Early research that has looked at the effectiveness of computer-mediated communication (CMC) in promoting interaction is encouraging, suggesting that it may indeed be superior to the (often teacher-dominated) language classroom in terms of the opportunities it affords" (p. 1). These opportunities, in turn, provide learners with an environment in which they can interact and exchange information contributing more to the negotiation of meaning with the result of overall learning improvement. As stated by Sauro (2009), "with the tools of technology making their way into the L2 classroom, corrective feedback delivered via written synchronous computer-mediated communication (SCMC) holds particular promise for the learning of especially complex or low salient forms ... during written interaction" (p. 96).

Sanz (2004) "found no difference between the effectiveness of explicit and implicit feedback in a CALL study which had students work at input processing activities" (Loewen\&Erlam, 2006, p. 3). Castañeda (2005) experimented on CF through both asynchronous and synchronous CMC. Findings of this study showed that instructors, responsible to provide feedback in this experiment, used asynchronous $\mathrm{CMC}$ more frequently than synchronous CMC.

Pellettieri (2000) also investigated implicit and explicit types of CF through electronic media and found positive results. Accordingly, she examined whether negotiation of meaning during task-based chat provide any chance for incorporation of CF into learning context. Results of this study suggested that the participants' negotiation of meaning during task-based chat improved and CF was also facilitated and applied more. He (ibid) supports feedback through $\mathrm{CMC}$ and states that "Because CMC fosters negotiation of meaning and form focused interaction and because students communicating through this medium have more time to process and monitor the interlanguage, I believe that CMC can play a significant role in the development of grammatical competence" (p. 83).

Tudini (2003) also supports that negotiation of meaning and CF through CMC facilitate learners' understanding of syntactic and grammatical issues.

Given the fact that feedback, regardless of its types and strategies, is mainly associated with learner and accommodators rich literature. However, any type of promotion and development including teacher's professional development depends on feedback. Since the focus of this study was on teacher education and teacher development, the following section addresses issues concerning teacher education and development and the way teacher can receive feed back as a mechanism of professional development.

\section{Feed back to Teachers}

It seems that provision of feedback to teacher which is one dimension of the present study can also lead to better and effective education and instructional objectives. Bear on the issue, Scheeler, Ruhl, and McAfee (2004) believe that teacher preparation programs are under scrutiny for their role in the troubled American educational system. Thus, teacher educators 
must encourage teachers to use effective teaching practices. One technique for increasing use of effective practices is providing feedback to teachers on both newly acquired and ingrained teaching behaviors. To determine attributes of effective performance feedback, a systematic search for empirical literature was completed. Analysis of the ten identified studies indicates attributes of feedback that have been studied fall into categories of (a) nature of feedback, (b) temporal dimensions of feedback, and (c) who gives feedback. Through this review, attributes of feedback were classified as either promising or effective practice in changing specific teaching behaviors. They found that only immediate feedback was identified as an effective attribute. Promising practices for feedback to teachers included feedback that was specific, positive, and/or corrective. These findings, recommendations and directions for additional research in feedback and teacher preparation are discussed.

Wragg (1971) explored on four groups of student teachers taught short lessons to small classes of children. They then retaught a similar lesson approximately one hour later to a comparable but different group of children. In the intervening one-hour period they received various kinds of feedback about the first lesson they had given. Analysis of the second lessons showed that the students who had both seen videotapes of their first lesson and been given information about their interaction with the class were likely to lecture less, elicit more spontaneous talk by the children and be rated higher by them.

Colvin, Flannery, Sugai, and Monegan (2009) state that educators face ongoing pressure to improve student outcomes, especially with regard to academic achievement and social behavior. One viable strategy for supporting and improving instructional practices is to conduct classroom observations and provide performance feedback. Researchers have shown performance feedback to be effective in the workplace, institutions, and educational settings. The present case study on a high school teacher provides preliminary promising information of the relevance and effectiveness of the combination of a classroom observation and a performance feedback process that focused on the relations among 3 key variables: classroom instructional settings, instructional practice, and classroom student behavior.

The authors used a process based on the observational data that identified when students were off task and pinpointed the corresponding setting categories and the teacher's instructional actions. The authors provided performance feedback to the teacher on the basis of these findings. Then, the teacher made changes in the identified setting categories and teacher actions, resulting in substantial gains in class engagement and a reduction in problem behaviors.

\section{Concluding Remarks}

Given the pertinent literature in line with respective empirical findings posed on four intermingled issues and based on the skeleton of this study, it can be seen that the outcome of research findings in the area of professional identity, journal writing, constructive feedback and teaching styles to a great extent match the six hypotheses being addressed in the present study.

On the perception of professional identity it can be seen, as Beijaard, Meijer and Verloop (2004) believe, the notion of professional identity has been perceived subjectively among scholars; nevertheless, a thorough understanding of the concept has a significant effect on the behavioral aspect of teacher's conduct mainly in classrooms and it seems to have gradual amendments in the process of their workshops. Other substantial studies Black and Wiliam (2008), Stiggins (2008b) support provision of constructive feedback in general to students and in particular to teacher. It should be also pointed out that scant attention has been directed to this trend in the area of teacher feedback provision via periodical journal writing and of any respective betterment, if any, in main stream education in general. The last concept corresponds 
to that of various teaching strategies and styles. Numerous definitions have been defined by scholars, i.e. (Conti, 1995, 2004; Felder \& Silverman 1988; Oxford, 1991).

Irrespective of theoretical consideration on the concept of teaching styles, operational findings reported in the literature indicate that exploitation of appropriate style by teachers can raise their practicality and empower the applicability of their teaching materials.

\section{CONCLUSIONS}

\section{For Teacher Educators}

As is the case with language teachers, teacher educators are under an ongoing scrutiny of their teaching practice on the part of student-teachers. They not only pay attention to subject matter issues, but also to the kinds of values that teacher educators display through their behaviors; teacher educators have high probabilities of becoming role models. The behaviors teacher educators display in their classroom on many occasions serve to develop in student teachers images of an ideal teacher they want to become. This is why teacher educators should engage in continuous self evaluation and reflection that enable them to realize the types of values that they are promoting through their interactions with student-teachers.

Teacher educators must similarly assess the stage of development in which studentteachers are in order to find appropriate learning opportunities for them. Experienced and novice teachers have different academic and professional needs and this was expressed in the stories of their lives. When teacher educators are aware of the real needs of the student-teachers with whom they interact, they are not only able to provide them with experiences that are tailored to their needs; they also give themselves the opportunity to learn from student-teachers.

Finally, the role of emotions in professional development and teacher self formation/transformation should not be overlooked. All the implications described above entail a strong emotional response from both student- teachers and teacher-educators since they demand care of the teacher self and a deep involvement of axiological frameworks. Studentteachers should be encouraged to understand the emotional responses that emerge when they are presented with new challenges in their lives as possibilities for empowerment and selftransformation.

The study also suggests that the combination of emotions, values and subjectivity emerged as an important process which can determine the extent to which language teachers are able to transform their selves and strengthen their agentive capacities. Greater efforts to value whole teacher selves that engage language teachers in reflection should be made in order to make teachers realize the potentials they have to transform and empower not only their teacher selves, but their learning lives of their students.

\section{References}

[1] Ammar, A., \& Spada, N. (2006). One Size Fits All? Recasts, Prompts and L2 Learning. Studies in Second Language Acquisition, 28, 543-574.

[2] Ancker, W. (2000). Errors and Corrective Feedback: Updated Theory and Classroom Practice. Forum, 38 (4), 20-28. Retrieved June 21, 2007 from http://exchanges.state.gov/forum/vols/vol38/no4/p20.htm 
[3] Ashwell, T. (2000). Patterns of Teacher Response to Student Writing in a Multiple-Draft Composition Classroom: Is Content Feedback Followed by Form Feedback the Best Method? Journal of Second Language Writing, 9, 227-258.

[4] Bee, R. \& Bee, F. (1998). Constructive Feedback. Institute of Personnel and Development in the Training Extras.

[5] Bitchener, J. (2008). Evidence in support of written corrective feedback. Journal of Second Language Writing, 17(2), 102-118.

[6] Bitchener, J., \& Knoch, U. (2008). The value of a focused approach to written corrective feedback. ELT Journal, 63(3), 204-211.

[7] Black, R. (1993). A match of Learning Style to Teaching Style Based on Use of Hemispheric Dominance Theory to Enhance Learning of Creative Thinking Skills. Unpublished Doctoral Dissertations, University of Georgia.

[8] Black, P. and Wiliam, D. (1998) Assessment and classroom learning. Assessment in Education 5(1), 7-74.

[9] Campillo, P. S. (2003). An Analysis of Implicit and Explicit Feedback on Grammatical Accuracy. Journal of English and American Studies, 27, 209-228.

[10] Carpenter, H., K. S. Jeon, D. MacGregor and A. Mackey (2006). Learners' Interpretations of Recasts. Studies in Second Language Acquisition 28(2), 209-236.

[11] Chandler, J. (2003). The efficacy of various kinds of error feedback for improvement in the accuracy and fluency of L2student writing. Journal ofSecond Language Writing, 12(3), 267-296.

[12] Colvin, G., Flannery, K. B., Sugai, G., \& Monegan, J. (2009). Using Observational Data to Provide Performance Feedback to Teachers: A High School Case Study. Preventing School Failure, 53(2), 95-104.

[13] Conti, G. J. (2004). Identifying Your Teaching Style. In Galbraith, Michael W. (ed) (pp. 76-91). Malabar, FL: Krieger Publishing Company.

[14] Daar, C., Fisher, J. (2004). Self-regulated Learning in the Mathematics Class. New Zealand Association for Research in Education (NZARE) conference, Palmerston North, 24-26 November 2004.

[15] Doughty, C., \& Varela, E. (1998). Communicative focus on form. In C. Doughty \& J. William (Eds.), Focus on form in classroom second language acquisition (pp. 114-138). New York: Cambridge University Press.

[16] Ellis, R. (2009). A Typology of Written Corrective Feedback Types. English Language Teaching Journal, 63, 97-107.

[17] Ellis, R., \& Sheen, Y. (2006). Re-examining the Role of Recasts in SLA. Studies in Second Language Acquisition, 28, 575-600.

[18] Ellis, R., Loewen, S., \& Erlam, R. (2005). Implicit and Explicit Corrective Feedback and the Acquisition of L2 Grammar. Studies in Second Language Acquisition, 28, 339-368.

[19] Erel, S. \& Bulut, D. (2007). Error Treatment in L2 Writing: A Comparative Study of Direct and Indirect Coded Feedback inTurkish EFL Context. Sosyal Bilimler Enstitüsü Dergisi Sayl, 22(1), 397-415. 
[20] Eş, Ş. (2003). Applying Focus on Form in EFL classes: Focus on Form through Input Flood, Output, and Corrective Feedback. Unpublished M.A. Thesis, Anadolu University, Institute of Educational Sciences.

[21] Farrar, Michael J. (1992). Negative Evidence and Grammatical Morpheme Acquisition. Developmental Psychology, 28(1), 90-98.

[22] Felder, R.M., and L.K. Silverman. (1988). "Learning and Teaching Styles in Engineering Education."

[23] Ferris, D. R., \& Roberts, B. (2001). Error feedback in L2 writing classes: How explicit does it need to be?. Journal of Second Language Writing, 10(3),161-184.

[24] Ferris, D. R. (2002). Treatment of Error in Second Language Writing Classes. Ann Arbor, MI: University of Michigan Press.

[25] Guenette, D. (2007). Is feedback pedagogically correct? Research design issues in studies of feedback on writing. Journal of Second Language Writing, 16(1), 40-53.

[26] Hattie, J. and Timperley.H. (2007). The Power of Feedback. Review of Educational Research, 77, 81-112.

[27] Hendrickson, J. (1978). Error Correction in Foreign Language Teaching: Recent Theory, Research, and Practice. Modern Language Journal, 62, 387-398.

[28] Hoban, G.F. (2004). Seeking Quality in Teacher Education Design: A Four-Dimensional Approach. Australian Journal of Education, 48(2), 117-133.

[29] Irons, A. (2008). Enhancing Learning through Formative Assessment and Feedback. London: Routledge.

[30] Kaweera, C., \& Usaha, S. (2008). The Impact of Different Types of Teacher Written Feedback on EFL University Students' Writing. KKU Res J (GS), 8(2), 83-94.

[31] Kim, H., \& Mathes, G. (2001). Explicit vs. Implicit Corrective Feedback. The Korea TESOL Journal, 4, 1-15.

[32] Lalande, J.F., II (1982). Reducing Composition Errors: An Experiment. Modern Language Journal, 66, 140-149.

[33] Lee, I. (1997). ESLLearners' Performance in Error Correction in Writing: Some Implications for Teaching. System, 25, 465-477.

[34] Leki, I. (1991). The Preferences of ESL Students for Error Correction in College-Level Writing Classes. Foreign Language Annals, 24, 203-218.

[35] Leowen, S., \& Erlam, R. (2006, February). Corrective Feedback in the Chatroom: An Experimental Study. Computer Assisted Language Learning, 19(1), 1-14.

[36] Liang, Y. (2008). The effects of error feedback in second language writing. Second Language Acquisition and Teaching, 15, 65-79.

[37] Lightbown, P. M. \& Spada, N. (1990). Focus on form and corrective feedback in communicative language teaching: Effects on second language learning. Studies in Second Language Acquisition, 12(4), 429-448.

[38] Lyster, R., \& Ranta, L. (1997). Corrective feedback and learner uptake: Negotiation form in communicative classrooms. Studies in Second Language Acquisition, 19, 37-66. 
[39] Lyster, R. (1998). Recasts, repetition, and ambiguity in L2 classroom discourse. Studies in Second Language Acquisition, 20, 51-81.

[40] Mackey, A. (2006). Feedback, noticing and instructed second language learning. Applied Linguistics, 27(3), 405-430.

[41] Maree, J.G., \& Fraser, W.J. (Eds). (2008). Outcomes-based assessment-facilitating best practice in classrooms. Heinemann: Cape Town.

[42] Nabel, T. and M. Swain 2002. Learner awareness of recasts in classroom interaction: A case study of an adult EFL student's second language learning. Language Awareness 11(1), 43-63.

[43] Oxford, R., M. Ehrman, and R. Lavine. (1991). "Style Wars: Teacher-Student Style Conflicts in the Language Classroom," in S. Magnan, ed.

[44] Panova, I., \& Lyster, R. (2002). Patterns of Corrective Feedback and Uptake in an Adult ESL Classroom. TESOL Quarterly, 36(4), 573-595.

[45] Pellettieri, J. (2000). Negotiation in cyberspace: The role of chatting in the development of grammatical competence. In M. Warschauer \& R. Kern (Eds.), Network-based language teaching: Concepts and practice (pp. 59-86). Cambridge: Cambridge University Press.

[46] Rezaei, S., Mozaffari, F., \& Hatef, A. (2011, March). Corrective Feedback in SLA: Classroom Practice and Future Directions. International Journal of English Linguistics, 1(1), 21-29.

[47] Richards, J., \& Rodgers, T. (2001). Approaches and methods in language teaching. New York: Cambridge University Press. $<$ http://dx.doi.org/10.1017/CBO9780511667305>

[48] Schmidt, R. (2001). Attention. In P.J. Robinson (Ed.), Cognition and Second Language Instruction (pp. 3-32). Cambridge, UK: Cambridge University Press.

[49] Schmidt, R. (1990). The Role of Consciousness in Second Language Learning. Applied Linguistics, 11(2), 129-158.

[50] Sheen, Y. (2007). The effect of focused written corrective feedback and language aptitude on ESL learners' acquisition of articles. TESOL Quarterly, 41(2), 255-283.

[51] Sheen,Y.,Wright,D.\&Moldawa,A.(2009).Differential Effects of Focused and Unfocused Written Correction on the Accurate of Grammatical Forms by Adult ESL Learners. System, 37(4), 556-569.

[52] Smith, M.C. (2005). The New Teacher Education: For Better or for Worse? Educational Researcher, 34(6), 181-206.

[53] Spada, N. and P.M. Lightbown. (1993). "Instruction and the Development of Questions In L2 Classrooms." Studies in Second Language Acquisition, 15, pp. 205-224.

[54] Stiggins, R.J. (2008) Assessment Manifesto: A Call for the Development of Balance Assessment Systems. A position paper published by the ETS Assessment Training Institute, Portland, Oregon.

[55] Truscott, J. (1996). The Case against Grammar Correction in L2 Writing Classes. Language Learning, 46, 327-369. 
[56] Tudini, V. (2003). Virtual immersion: native speaker chats as a bridge to oral interaction. Manuscript submitted for publication.

[57] White, L., Spada, N., Lightbown, P. M., \& Ranta, L. (1991). Input Enhancement and L2 Question Formation. Applied Linguistics, 12, 416-432.

[58] Widdowson, H. G. (2003). Defining Issues in English Language Teaching. Oxford: Oxford University Press.

[59] Zhang S. (1995). Reexamining the affective advantage of peer feedback in the ESL writing class. Journal of Second Language Writing, 4(3), 209-222. 